\title{
ASSESSMENT METHODS FOR IMPACT OF ENVIRONMENTALLY FRIENDLY ENTREPRENEURSHIP AND DRIVING FORCES TO THE QUALITY OF ENVIRONMENT
}

\author{
L. FROLOVA and D. KAUZENA \\ Faculty of Economics and Management, University of Latvia \\ Aspazijas bulvaris 5, Rīga, LV-1050, Latvia \\ E-mail: frolova@lanet.lv, dace_kauzhena@hotmail.com
}

Received September 282001

\begin{abstract}
Environmentally friendly entrepreneurship (further - EFE) is one of the tools for improvement environmental quality. There might be made theoretical approaches, how quantitatively large is the impact of the EFE in changes of the quality of environment. In this field theoretical suggestion is prior to practice, because in the most of countries there is domination of several cases, but it could not be used as overall tendency [8; 10]. Opposite impact to quality of environment might be created by driving forces (driving forces are economical indicators, which stimulate changes in quality of environment) [1] like overconsumption, growth of gross domestic product (further - GDP) etc. The article will highlight three possible approaches: 1) the assessment of EFE and driving forces to environmental quality; 2) quantitative analysis of interaction between environmental pressure (pressure indicators characterized impact of enterprises made to environment) indicators and driving forces indicators. In the second part there will be compared four countries: Baltic states and Sweden and 3) descriptive analysis of interaction between enterprise size and positive arrangements according environmental protection in Latvia in 1999 and 2001. Mainly there will be used the method of mathematical modelling [6] - descriptive, regression and power models and their attributes.
\end{abstract}




\section{PROBLEM DESCRIPTION}

Pollution prevention should be estimated as obligatory additional costs to any everyday activities in enterprises. Enterprises following EFE descriptions [9] are reducing pollution by saving and accounting resources during the whole life cycle of their production. Also they are planning the design of their products so that these products could be re-used and also re-cycle. Besides $\mathrm{EFE}$ enterprises have expected to introduce the take-back facilities of their production.

In practice there are very few of EFE enterprises, e.g. in Latvia there are less than $1 \%$ of enterprises, which assessed environmental indicators as fulfilled in their enterprises in 1999 [7;9] and also in 2001. The analysis of impact of EFE to the quality of environment will be more acceptable if there will be more years observed according EFE. What concerns driving forces - there is larger opportunity to assess these relations - there might be precise analysis how most of the states in economical transition have based their economies on resources or economical fields, which have created additional pressure to environment (e.g., air pollution, soil degradation etc).

\section{TARGET SETTINGS}

In all three forms of models there are similar main targets: improvement of understanding and acting as EFE at enterprise level or advanced consumer at level of consumption.

1) In the first model, there should be made emphasis to pollution reduction and also reduction of non-efficient resource usage;

2) In case of analysis of relations between the driving forces and pressure indicators there should be observed relations highlighted that the pressure indicators are not the only, which impact the growth of economy;

3) The last case briefly shows the relations of the enterprise size (evaluated by number of employees per enterprise) and EFE methods presence at enterprise.

\section{ASSESSMENT METHOD OF THE IMPACT OF EFE AND DRIVING FORCES TO ENVIRONMENT}

The model consists of three main items:

1) driving forces - e.g. GDP, quantitative measures of economical fields;

2) EFE - average number of EFE enterprises in economy total and also per field;

3) indicators of eco-efficiency - also titled as pressure indicators, e.g. pesticide, $\mathrm{SO}_{2}$ pollution. 
In general this model could be described by regression equation:

$$
a+b_{1} x_{1}+b_{2} x_{2}=y
$$

where $y$-indicators of environmental pressure in $t$-year; $x_{1}$ - average number of EFE enterprises in $t$-year; $x_{2}$ - quantitative measures of driving forces in $t$-year; $b_{1}, b_{2}$ - coefficients characterizing changes of quality of the environment, in case of changes in above-mentioned variables; $a$ - in our model there is no interpretation, because the pollution could not be reduced till 0 .

Main restrictions are the following

1) in case of $x_{1}$ - the total number of enterprises;

2) in case of $x_{2}$ - consumption minimum per inhabitant.

If we assume that sustainable development means more or less minimal creation of harmful elements to environment, then in optimal case $y=0$. This is shown in the equation

$$
a+b_{1} x_{1}+b_{2} x_{2}=0
$$

where $y=0$ is global optimum position, which could be stated as our goal, but firstly there should be achieved the aim $y_{t}>y_{t+1}$, where $t$ is actual year.

Further there will be two assumptions:

1) $x_{1}$ as endogenous variable;

2) $x_{2}$ as endogenous variable.

In case $x_{1}$ is endogenous (invariable consumption), after the calculations we can get the result, which quantitatively shows how many there should be enterprises with environmental management for complete reduction of pressure to environment.

In case $x_{2}$ is endogenous (invariable number of EFE enterprises), we can find out how considerable should be the decreasing of driving forces to achieve the zero level of harmful processes to environment. According to classification of mathematical models [6], above mentioned model should be characterized as:

1) functional model, because the results could be used in decision making process in environmental regulation;

2) in scope of research it is macro economical model, because it does not make any consideration of the individual enterprises. If there is a need to see the efficiency of EFE, it can be also used for analyzing micro level data;

3) dynamic model, because of used time series. For longer time series the results will be more precise;

4) linear model, because in scope of this research there is still only three years of observations according EFE and the main aim is to see this principle as it could function;

$5)$ open model, because there is a dominance of exogenous parameters;

6) descriptive model, because it shows the tendency in actual data (the only exception is the circumstances when $y=0$ ); 
7) in scope of research the model is deterministic, because there was made analysis of main factors, which influenced the results;

8) whole and fraction numbers model, because the number of EFE enterprises always will be whole numbers, but indicators of environmental quality could be also expressed as fraction numbers;

9) balance model, since there is pre-defined target, then the result will be precisely expressed number of EFE or quantitative results, which show exactly how much we should reduce consumption;

10) in scope of research the model is unitary model, but since the input of the model can be calculated as output of the other sub models, then it can also be the complex model or models system.

What concerns only the impact of the EFE to quality of environment, then this assessment is not practically used (as mentioned before). There could be made analysis of special cases [4] of enterprises, which fulfill EFE in practice. But this is not the scope of this article. Implementation of the model is mainly for purpose to demonstrate, how in practice this model should function. It is technology, by which there could be observed pressure of driving forces and impact of EFE enterprises to environment. Survey made for observing EFE, is only for two years (1999 and 2001, also there was made interpolation for 2000), that's why also driving forces variables were used for three years only. The implementation of such model is based on practice in Sweden, where surveys were made according Environmental management in enterprises [8] with considerable time distance (1991 and 1998) and so far only twice. Unfortunately the obtained results contain too large statistical errors and they are not useful for decision making process in this field, but it can be used in future, when time series enlarge.

\section{ASSESSMENT METHOD OF THE IMPACT OF EFE AND DRIVING FORCES TO ENVIRONMENT}

The assessment model is like in equation (3.1), just in this case there is additional indices for state and also variables have different explanation

$$
a+b_{1 j} x_{1 j}+b_{2 j} x_{2 j}=y_{j},
$$

where $y$-GDP, mln EUR in $t$-year of $j$-state; $x_{1 j}$ - total felling of forest, thousands $m^{3}$ in $t$-year of $j$-state; $x_{2 j}$ - road cargo turnover, mln tonnekilometers in $t$-year of $j$-state; $b_{1 j}, b_{2 j}$ - coefficients characterized changes in GDP, in case of changes in above-mentioned variables; $a$ - in our model there is no interpretation, because the GDP could not reach 0 level.

Next we compare four countries $[2 ; 3 ; 5 ; 13]$ and as the unit equalizing data we used $\mathrm{km}^{2}$. There could be observed that Baltic states, despite of presumption of their non-environmental attitude to their forests, are less felling their forest resources then Sweden. Most extensive in cutting are Latvian entrepreneurs, what could be valuated less positive then e.g. Lithuania, which is 
more saving their forests. The differences among Baltic states variables (GDP, forest felling and road cargo turnover) are not significant (by $F$ criteria) per $1 \mathrm{~km}^{2}$ and also per 1 inhabitant of countries. There is a significant difference between Sweden and Baltic states data according forest felling, GDP, but not according cargo turnover. By using this model there are made calculations for four countries. The results are expressed in the following equations:

Sweden:

$$
109,339.16-1.46 x_{1}+6.35 x_{2}=y
$$

Lithuania:

$$
8,134.37-0.93 x_{1}+0.26 x_{2}=y
$$

Latvia:

$$
2,551.46+0.08 x_{1}+0.19 x_{2}=y
$$

Estonia:

$$
2,332.7+0.02 x_{1}+0.17 x_{2}=y
$$

$t$-test:

Further there will be brief review of hypothesis, if $H_{0}: B=B_{0}$, what proves suggestion if there is significant influence of factors to independent variable. If we use previously calculated $t$-statistics for coefficients accordingly the above given equations, we get results with the theoretical value of $t$ (degrees of freedom $=n-k$ [12], which in our case is equal 4 , at probability 0.9 , which is enough in analysis of economical circumstances). The result is that $t=2.318$, which is much greater than all of given empirical $t$-statistics (exception is road cargo turnover in Sweden) for regression coefficients. This fact explains that $H_{0}$, should be rejected $H_{0}$, there is no significant impact of these factors to changes in GDP in Baltic states.

Standardization of regression coefficients:

Main reason for this process is comparison of importance level of different factors to independent variable. The question which of the factors are more related to GDP, can be answered by using standardization method (see equations: (4.7), (4.8), (4.9) and (4.10)). The algorithm for beta coefficients [12] is used as in (4.6) [11]:

$$
B_{j}=\frac{b_{j} * s_{j}}{s_{o}}
$$

where $B_{j}$ - beta coefficient of $j$ - state; $s_{j}$ - is standard deviation of factorial indication in $j$-state; $s_{o}$ - is standard deviation of independent variable in $j$ - state.

The results are the following (where $z$ is standardized form of variables and all coefficients keep the same meaning as in (4.1)):

Sweden:

$$
-0.315 z_{1}+1.0063 z_{2}=z_{0}
$$


Lithuania:

$$
-0.553 z_{1}+0.423 z_{2}=z_{0}
$$

Latvia:

$$
0.470 z_{1}+0.509 z_{2}=z_{0}
$$

Estonia:

$$
0.309 z_{1}+0.667 z_{2}=z_{0}
$$

In (4.7) and (4.8) there is a positive tendency not to exploit the forest resources to reach the growth of GDP. In case of forest felling there is bad example of Latvia (see (4.9) equation), because it really puts a big pressure to its forests to get some profit only from export raw wood materials. Estonia (see (4.10) equation) is more oriented to cargo turnover on roads then on forests. It is again a pressure to air pollution, but such tendency is typical to countries in transition and also in developing countries. If we use partial regression, we can follow how independent variable is changed in case of constant one of the factors. Situations are quite opposite in Estonia and Lithuania, because if Lithuania keeps unchanged road cargo turnover then GDP could decrease, but in Estonia there will be observed growth in GDP, if it will be based only on cargo turnover. The first circumstances are more positive for environment, because it clearly shows, that in Lithuania there is no additional pressure to forest resources. Latvian case is flexible because both factors influenced economy quite similar.

\section{ENTERPRISE SIZE AND EFE}

As the scatter diagram allows to conclude, there is appropriate quality of linkage between enterprise size and number of positive answers per enterprise according environmental protection issues in entrepreneurship. Mainly these relations could be described by hyperbolic and power models. According to obtained results [7] calculations obtained there were made of data in 1999 and 2001 for power functions:

$$
\begin{aligned}
& y=7.1729 x^{0.0865}, \\
& y=7.6004 x^{0.0847},
\end{aligned}
$$

where independent variable $x$ is the number of employees per enterprise and $y$ is the number of positive answers according environmental issues per enterprise $[10 ; 9]$.

Using hyperbolic functions for 1999 and 2001 we obtain:

$$
y=10.0490-2.3452 / x,
$$




$$
y=11.5573-6.0480 / x .
$$

These functions show that there is possibility of increasing of positive answers per enterprise in case there is increase of number of employees per enterprise. The other analytical calculations like correlation coefficients and standard deviation show that chosen functions are with the largest level, but still quite weak (less than 0.6) in their probability. And so far there should be made at least enlarging of sample size (now $n=800$ ) for stabilizing of results obtained.

\section{CONCLUSIONS}

Environmental improvement and economical development are opposite and unrelated issues in practice. Very rarely there could be found some countries, which broadly follow environmentally friendly entrepreneurship. Usually there are some kinds of activities, which are degrading environment, but which should improve the growth of economy. Mathematical modelling of regression models and also optimization models could be very convenient method for assessment differences among different countries and also for forecasting. Unfortunately the first theoretical assumptions according EFE impact to environmental quality is only theoretical because of lack of statistical data series. But as there is beginning of data collection in Latvia in field of EFE, this model can be practically implemented and realized as well. Main results from the second part of regression models: there is clear picture of similarities between Baltic states, but also there are some points to be taken into account: 1) in Latvia there should be changed the pressure to forest felling and exporting of quite raw forest materials to some more processed wood products; 2) in Lithuania there is nice tendency for saving forests; 3) in Estonia also there is less pressure to forest, and they put their stress to transit services. Also the other main suggestion is that Sweden is not the state, which bases its economical growth to natural resources or fields, which create air pollution. However Sweden is far in front of all Baltic states in both analyzed fields (they are significantly bigger consumers of forest products and also road cargo per inhabitant or per $1 \mathrm{~km}^{2}$ ). This shows that there is no such complete environmentalism in practice in Sweden. 


\section{REFERENCES}

[1] Environmental assessment report. Environmental signals 2000. Copenhagen: EEA, 2000.

[2] Statistical Yearbook of Latvia 2000. R.: Central Statistical Bureau of Latvia, 2000.

[3] Statistical Yearbook of Lithuania 2000. Vilnius: Central Statistical Bureau of Lithuania. Methodical Publishing Centra, 2000.

[4] Experience and results of Environmental Management Systems implementation in the Latvian pharmaceutical industrial. Latvian Pollution Prevention Centre. R.: Latvian Development Agency, 2001.

[5] Statistical Yearbook of Sweden 2001. Stockholm: Statistics Sweden, 2001.

[6] L. Frolova. Mathematical modelling of economical processes. R.: Biznesa augstskola Turba, 1999. (in Latvian)

[7] L. Frolova and D. Kauzena. Environmentally friendly entrepreneurship in Latvia: is there any difference between 1999 and 2001? In: Proc. of the 7th Environmental Roundtable on Cleaner Production Lund: IIIEE, 2-4th May, 2001.

[8] P. Heidenmark. Environmental Management in Swedish Manufacturing Industries. Lund: IIIEE Reports (14), 2000.

[9] D. Kauzena. Environmentally Friendly Entrepreneurship in Latvia. Questionnaire. Riga: University of Latvia, 1999, 2000, 2001. (in Latvian, Russian and English)

[10] D. Kauzena and M. Vircavs. Environmentally Friendly Entrepreneurship in Latvia. Riga: University of Latvia, 2000. (in Latvian)

[11] O. Krastins. Statistics and econometrics. R.: Statistical institute of Latvia, 1998. (in Latvian)

[12] R. Ramanathan. Statistical Methods in Econometrics. Academic Press, -NY: Inc. Harcourt Brace Jovanovich. Publishers, 1993.

[13] Statistical Yearbook of Estonia 2000. Tallinn: Central Statistical Bureau of Estonia, 2000.

\section{Aplinkai draugiško verslumo ir varančiuju jègu įtakos aplinkos koky- bei metodu ivertinimas}

L. Frolova, D. Kauzena

Aplinkai draugiškas verslumas (ADV) - viena iš priemonių aplinkos kokybès gerinimui. Galima bandyti teoriškai parodyti, kaip aplinkos kokybès pasikeitimus ittakoja ADV. Šioje srityje teoriniai pasiūlymai nei praktinis panaudojimas, kadangi daugumoje šaliụ vyrauja skirtingi būdai, bet tai negali būti naudojama kaip bendroji tendencija. Aplinkos kokybei priešingą įtaką gali kurti varančios jẻgos (varančios jẻgos yra ekonominiai indikatoriai, kurie stimuliuoja aplinkos kokybès pasikeitimus) tokios kaip pervartojimas, bendrojo vidaus produkto augimas ir t.t. Straipsnyje nušviečiami trys galimi aspektai: 1) ADV ir varančiưjų jègu įtakos aplinkos kokybei įvertinimas; 2) kiekybinè sąveikos tarp aplinkos spaudimo indikatoriụ (šie indikatoriai charakterizuoja įmonių spaudimą aplinkai) ir varančiụjų jègụ indikatorių. Antrojoje dalyje lyginamos keturios šalys: Baltijos šalys ir Svedija ir 3) sąveikos tarp i̇monès dydžio ir teigiamu aplinkos apsaugos priemoniu Latvijoje 1999 ir $2001 \mathrm{~m}$. analizè. Čia naudojamas matematinis modeliavimas - aprašomieji, regresiniai ir jegos modeliai ir jų atributai. 